\title{
Paideusis
}

\section{Theology and the Curriculum}

\section{Jay Newman}

Volume 1, Number 2, 1988

URI: https://id.erudit.org/iderudit/1073424ar

DOI: https://doi.org/10.7202/1073424ar

See table of contents

Publisher(s)

Canadian Philosophy of Education Society

ISSN

0838-4517 (print)

1916-0348 (digital)

Explore this journal

Cite this article

Newman, J. (1988). Theology and the Curriculum. Paideusis, 1(2), 12-22.

https://doi.org/10.7202/1073424ar

This document is protected by copyright law. Use of the services of Erudit (including reproduction) is subject to its terms and conditions, which can be viewed online.

https://apropos.erudit.org/en/users/policy-on-use/ 


\section{Theology and the Curriculum}

\section{Jay Newman, University of Guelph}

Questions about what place, if any, theology should have in curriculum have been with us almost as long as theology itself. For several reasons, such questions merit special attention at this time, and particularly from philosophers of education in Canada.

(1) The controversial decision of successive governments in Ontario to extend provincial funding of Roman Catholic schools has stimulated a great deal of informal and sometimes careless reflection about a whole constellation of issues concerning the relation of religious, educational, and political institutions; and it is appropriate that philosophers of education in Canada fulfill their social obligation to shed some light on such issues.

(2) In the last few years, there has been a lively and sometimes bitter debate among Canadian scholars in the field of religious studies about whether the academic study of religion needs to be made more scientific and less theological, 1 and some participants in this discussion have attached particular importance to the presence of religious studies programmes in provincially-funded, non-sectarian institutions of higher learning. ${ }^{2}$ Moreover, for some years now, associations of religious studies scholars in Canada have found themselves pressed by governmentally-funded granting agencies to guarantee that their subsidized research and publications will not be denominationally biased.

(3) In Canada, as in the United States and many other countries, there has been a marked increase in public criticism by fundamentalist and other religious groups of the "secular humanist bias" of public school curricula. This criticism has taken on added importance as a result of the increasing political muscle of such groups.

(4) In recent years, there have been several widely publicized cases in which noted teachers of theology (such as Hans Kung and Charles Curran) have been stripped of a certain status by the hierarchy of their church, and such actions have been seen by some observers as compromising the integrity of theology as an academic discipline. I shall be concentrating in this paper on a classic argument about the place of theology in university curricula. However, toward the end of my discussion, I shall broaden the scope of my observations and relate my little piece of textual analysis to some practical issues of the day.

Though more than a century has passed since its initial publication, John Henry Newman's collection of lectures, The Idea of a University, is still seen as a major philosophical statement on the na- 
ture and aims of higher education. Even anti-religious academics sometimes quote approvingly from the celebrated Roman Catholic churchman's work on the university, for nowadays The Idea of a University is usually remembered as a definitive defense of the ideal of liberal education. Consider this famous passage:

This I conceive to be the advantage of a seat of universal learning, considered as a place of education. An assemblage of learned men, zealous for their own science, and rivals of each other, are brought, by familiar intercourse and for the sake of intellectual peace, to adjust together the claims and relations of their respective subjects of investigation. They learnt to respect, to consult, to aid each other. Thus is created a pure and clear atmosphere of thought, which the student also breathes, though in his own case he only pursues a few sciences out of the multitude. He profits by an intellectual tradition, which is independent of particular teachers, which guides him in his choice of subjects, and duly interprets for him those which he chooses. He apprehends the great outlines of knowledge, the principles on which it rests, the scale of its parts, its lights and shades, its great points and its little, as he otherwise cannot apprehend them. Hence it is that his education is called "liberal." A habit of mind is formed which lasts through life, of which the attributes are freedom, equitableness, calmness, moderation, and wisdom; or what in a former discourse I have ventured to call a philosophical habit. This then I would assign as the special fruit of the education furnished at a university, as contrasted with other places of teaching or modes of teaching. This is the main purpose of a university in its treatment of its students. 3

Here is a statement of one of two central themes of The Idea of a University, but there is a second that, though more important in Newman's eyes, rarely receives as much attention. I refer to Newman's thesis that it is not "consistent with the idea of university teaching to exclude theology from a place among the sciences which it embraces." 4 This thesis is introduced in The Idea of a University are devoted to explaining and defending it. Many contemporary educators who loudly praise Newman's defense of liberal education are puzzled by the importance that Newman assigns to this second theme.

Newman's basic argument in defense of the thesis is straightforward and valid. He writes: 
It is the fashion just now, as you very well know, to erect so-called universities without making any provision in them at all for theological chairs. Institutions of this kind exist both here [Ireland] and in England. Such a procedure, though defended by writers of the generation just passed with much plausible argument and not a little wit, seems to me an intellectual absurdity; and my reason for saying so runs, with whatever abruptness, into the form of a syllogism-A university, I should lay down, by its very name professes to teach universal knowledge: Theology is surely a branch of knowledge: how then is it possible for it to profess all branches of knowledge and yet to exclude from the subjects of its teaching one which, to say the least, is as important and as large as any of them? I do not see that either premises of this argument is open to exception. 5

Both premises are indeed "open to exception," and Newman's argument is unsound. But the argument is valid: if universities should teach all (important) branches of knowledge, and if theology is one of the (important) branches of knowledge, than an institution that excludes theology from its subjects cannot be a true university.

Consider the premises. Newman says that a university, by its very name, professes to teach universal knowledge. Is this so? No student of etymology will fault Newman for associating the term "university" with the term "universal"; but must a university profess to teach universal knowledge? For the medieval, the universitas was a corporation, a community of scholars, and it was more its corporate character than the breadth of its curriculum that led the medieval to call a school like that at Bologna or Cambridge a "university." Not one of the great medieval universities provided instruction in all areas of knowledge; even when there were relatively few sciences, no university, not even Paris, could provide instruction in all known areas of knowledge. Practical factors made such an achievement virtually impossible; and if it had been possible for the medieval, it would certainly have been impossible by Newman's time. Still, while universities should not and ordinarily do not profess to teach universal knowledge, perhaps they have sometimes professed to provide instruction in all the more important branches of knowledge. Even this more limited profession would be imprudent. Some of the earliest universities stressed medicine while others stressed arts and theology. Many greatly respected universities have not provided instruction in such obviously important areas as medicine, jurisprudence, economics, anthropology, and geology. The university that Newman himself founded in Ireland offered instruction in very 
few areas, as Newman could only afford to hire a small number of professors. 6 He must have felt then that most of the subjects taught at the larger, established universities were not particularly "important."

What branches of knowledge are most important? Despite Newman's intuitions, this question is not easily answered. In the Communist countries, theology is usually not considered a branch of knowledge at all, much less an important one. In arguing that it is self-evident that theology is an important branch of knowledge, Newman is preaching to the converted. Those writers "of the generation just passed"7 probably did not agree with him. And as our own society has become more secularized, faculties of theology have become conspicuously smaller than "rival" faculties of biology, literature, psychology, and economics. Many have disappeared completely.

Thus, as Newman's first premise is questionable, so too is his second. The fact that theology is so often excluded from the curriculum of institutions that are almost universally recognizad as universities-such as my own, The University of Guelph, which has dozens of academic departments but not one course in theology - indicates that many influential and educated people either do not regard theology as a branch of knowledge, or do not regard it as an important branch of knowledge, or do not believe that it is important enough to qualify as one of the core subjects of university teaching and research.

Newman is not focussing his criticism on the attitude of atheists toward the teaching of theology; as a Victorian, he does not take atheists very seriously. He is more disturbed by the attitude of certain self-professed religious believers. He is puzzled by the fact that many people who believe that we can have knowledge of God want to keep that knowledge away from university students. For Newman:

Religious doctrine is knowledge, in as full a sense as Newton's doctrine is knowledge. University teaching without theology is simply unphilosophical. Theology has at least as good a right to claim a place there as astronomy. 8

Here is a response not only to atheists but to certain religious "liberals" as well. And against the latter he adds, "if, then, in an institution which professes all knowledge, nothing is professed, nothing is taught about the Supreme Being, it is fair to infer that every individual in the number of those who advocate that institution, supposing him consistent, distinctly holds that nothing is known for certain about the Supreme Being: nothing such as to have any claim 
to be regarded as a material addition to the stock of general knowledge existing in the world."9 In Newman's view, the "liberals" fail to see that theology is not only an important subject but is of supreme importance in the curriculum, for "religious truth is not only a portion but a condition of general knowledge." 10

The "liberal" does not have to take all this criticism lying down. He can observe that many scientists and intellectuals seem to get on quite well with their work even without Newman's "condition of general knowledge," religious truth; and he can suggest that if theology is a kind of knowledge, it must be knowledge of a rather personal kind, for theologians do not agree with one another nearly as much as chemists or mathematicians do. Lutherans, Jews, and Moslems can agree with Newman's thesis that theology deserves a place in a university curriculum, but their theologies and ideas of religious truth are significantly different from Newman's. Even Roman Catholic theology teachers have been criticized or condemned by the hierarchy of their church for certain theological pronouncements, and I am thinking here not only of people like Kung and Curran but of Cardinal Newman himself, who was much mistrusted by many of his ecclesiastical superiors. In any case, most believers as well as unbelievers have not, since the Enlightenment, trusted theologians as much as they did in the High Middle Ages, and most of them have come to conceive of religious faith more as a matter of personal commitment than a passive awareness of objective truths.

An important development in recent years has been the emergence of a new type of "liberal" theology, and some advocates of this new liberal theology have argued that while theology merits a place in the university curriculum, it must be theology of a flexible and progressive type. These thinkers, instead of talking all the time about truth and knowledge, talk more about perspective, world-view, spiritual health, and the cultural value of religion. But is such "theology" genuine theology, or is it psychology, anthropology, or ethics masquerading as theology? Reflection on this question may give us a new insight into Newman's thesis. Consider an analogy between the relation of such "liberalism" to theology and the relation of behaviorism to psychology. There was a time when most psychologists actually believed that they were studying the psyche (soul); this is not hard to understand, for to study the psyche, one must believe that there is a poyche to be studied. But most people in Canada now who call themselves "psychologists" and teach psychology courses in universities do not seem to believe that a poyche exists. What then are they studying? They usually tell us that they are studying matters that earlier generations of thinkers explained by reference to a payche, such as motivation and learning. Similarly, many people who now call themselves "theologians" and 
teach theology courses in universities do not seem to be seeking and passing on knowledge about God or the Divine but seem rather to be social and behavioral scientists.

In his Preface to The Idea of a University, Newman invites us to consider why the Vicar of Christ has encouraged the establishment of Christian universities. Surely, Newman observes, "his first and chief and direct object is, not science, art, professional skill, literature, the discovery of knowledge, but some benefit or other, to accrue, by means of literature and science, to his own children; not indeed their formation on any narrow or fantastic type, as, for instance, that of an English gentleman may be called, but their exercise and growth in certain habits, moral or intellectual."11. But the university does not simply make students more virtuous; it makes them better in its own special way. The university does not have precisely the same role as the church, family, or state, though all of these institutions aim partly at making people better. Its mission is essentially and inextricably tied up with intellectual activity. It is a place where, first and foremost, knowledge is acquired and passed on. Consider the first central theme of Newman's lectures: the university is a seat of universal learning; it is an assemblage of learned men; it embodies an intellectual tradition; it helps students to apprehend the outlines of knowledge; it aims at the formation of a philosophical habit; and it professes to teach the more important branches of knowledge. So though the university is concerned with moral values and moral habits, it is essentially concerned with the understanding and promotion of them by means of an intellectual quest for knowledge.

While we must question Newman's thesis that an institution which excludes theology from the subjects of its teaching cannot be a true university, we can agree with him that no Christian university can afford to exclude theology from its subjects. This is no small point, even if is a much smaller one than that which Newman tries to establish in his lectures. Secular universities are, by their very nature as secular institutions, either neutral in principle with regard to questions of religious doctrine or hostile in principle to all religious doctrine. In our society, they are neutral in principle rather than hostile, and the religious affiliation (or non-affiliation) of their members is of no special importance. Newman was invited by the Irish Catholic hierarchy to help found a Catholic university in Ireland. The foundation and support of religious colleges could be the most appropriate response to the increasing secularization of established universities. It is the founders and supporters of religious colleges who must pay careful attention to the second central theme of Newman's lectures. A raison d'etre of the religious college could be that it is committed to the principle that theology is an important branch of knowledge and perhaps even the most important. Thus, I(2), Spring, 1988 
traditionally, a primary raison d'etre of a Roman Catholic university is that it is committed to the principle that Roman Catholic theology is an important branch of knowledge.

For those "liberal" professors of theology who see their role as involving almost anything and everything but the dissemination of knowledge about God or the Divine, theology is to be reduced to psychotherapy, anthropology, applied sociology, history of ideas, and so on. Now, a Christian university is not only a Christian institution; it is a university, and its role is not the same as that of other Christian institutions. It may not be enough for a Christian university to be committed to the teaching of something called "theology"; perhaps it ought to be committed to the principle that the theology it teaches provides students with genuine knowledge about the Divine, something that is knowledge in as full a sense as Newton's doctrine or the modern astronomer's doctrine is knowledge.

Newman is wrong in believing that secular universities are not true universities. His definition of a "university" is stipulative and arbitrary. There are many sincere and appropriate disagreements between groups of scholar-educators as to what qualifies as knowledge, important or otherwise. Newman's attack on secular universities is no more potent than, say, the Marxist's attack on Christian universities that fail to teach the "true" teachings of Marx and Engels. This is not to say that the teachings of Marx are as sound as those of Thomas Aquinas, but merely a reminder that each and every university has a curriculum that to some extent reflects its founders', leaders', and supporters' views of what qualifies as genuine and important knowledge. Every university, secular as well as religious, has a curriculum that reflects such commitments. One valuable aspect of Newman's argument is that it draws our attention to one raison d'etre of religious institutions of higher learning. It also warns educators to be on guard against a corrupting influence in such institutions, for if a religious school is to have a raison d'etre, perhaps it must not only include theology among the subjects of its teaching but must treat theology as an important branch of knowledge about the Divine. Moreover, it may have to indicate the implications of theological knowledge for the teaching done in other subject areas. As we have seen Newman observe, learned persons in a university "are brought ... to adjust together the claims and relations of their respective subjects of investigation." 12

We should not take for granted the synthetic approach to religious higher education that has evolved in many major Canadian universities. While these universities are in a sense essentially secular-so as to enable even the confirmed atheist to carry on his work with a minimum of discomfort-they allow for the teaching of theology (and compatible instruction in other areas) in various af- 
filiated denominational colleges, while simultaneously allowing for the philosophical, social- scientific, and critical study of religion in ecclesiastically independent faculties.

When we consider religious primary and secondary education in Canada, we are faced with a somewhat different constellation of philosophical issues than when we consider religious higher education, but it is still the case that a fundamental distinction between public and religious schools lies in their approach to the matter of theological knowledge. In a society which has intelligently come to grips with the fact of cultural pluralism and the need to promote religious tolerance, the public school must accommodate teachers and students who either do not believe that theology is an important (or genuine) form of knowledge or do not believe that the teaching of theology can safely be entrusted to a publicly-administered institution. Yet a thoughtful, fair-minded unbeliever can be brought to appreciate the view of the religious school supporter that the curriculum of a public school cannot do justice to the latter's conception of the central role of theology among the subjects of knowledge. Whether such an unbeliever can or should be brought to see that religious schools should be supported by funds from the public purse is, or course, another question.

In dealing here with some questions about what place, if any, theology should have in certain curricula, $I$ have not gone far toward solving the great problems that torment those who regularly reflect on such matters as church-state relations, educational ideals, and conditions of religious tolerance. ${ }^{13}$ Yet I suggest that even with the narrow perspective that has been developed in this analysis, we can appreciate better some of the complexities involved in the controversies described at the outset of our investigations.

(1) In defending the foundation, maintenance, and (particularly) public financial support of denominationally-administered "separate" or "parochial" schools at any level, leaders of denomination X may advance various arguments, but if they are to persuade the defender of the public school system, they may sooner or later have to argue that only their separate schools can do an adequate job of teaching and promoting what they take to be theological knowledge. If they do not argue in this way, they will be rather more vulnerable to the criticism that they are gratuitously promoting the kind of particularism that often leads to intolerance and destructive division in society. In any case, for the typical religious believer, religious faith is not simply a matter of mere opinion or perspective but a commitment to a world-view that he sees as involving the most plausible available conception of reality.

When appealing for support funds from the public purse, leaders of $X$ may owe it to their fellow citizens to be able to explain why it is insufficient for them simply to supplement public school instruction 
with theological education provided at their own expense. They may need, among other things, to be able to indicate to their fellow citizens the reasons that they have for regarding the public school curriculum as fundamentally in conflict with what they take to be theological truths, and the reasons that they have for believing that errors in the public school teaching programme cannot satisfactorily be "corrected" by a supplementary theological programme funded at their own expense. The reasons that they give will not be beyond criticism. In any case, the government should tread lightly here, for if it is not prepared to provide funding for the separate schools of every denomination that petitions for it, it may well find itself in the position of endorsing (or at least seeming to endorse) some theologies as at least "acceptable" while rejecting others as "unacceptable", especially if its decisions are not based exclusively on the actual degree of conflict between public school teaching and the teaching of petitioning denominations. And alternatively, if it provides funding for the separate schools of every denomination that petition for it, it will effectively destroy the public school system, an institution which, for all its flaws, has contributed greatly to the promotion of both religious tolerance and social unity. The government must be careful that in its zeal to extend religious liberty, it does not implement policies that will ultimately undercut the very foundations of religious liberty.

(2) Some scholars who argue that the study of religion needs to be made more scientific and less theological do not pay enough attention to the arguments given by theologians to establish that theology is itself a science. The disagreement here rests partly on conflicting philosophies of science and conflicting epistemologies, and there is much in these areas to be debated. Still, when governmentallyfunded granting agencies treat theological research and writing as if they were necessarily nothing more than disguised religious propaganda, they not only endorse a particular philosophy of science and a particular epistemology, but they show a remarkable contempt for a very wide range of world-views. We might begin by reminding them that Aristotle, to whom we owe the core of our traditional classification of the sciences, considered theology theologike to be the science par excellence, though he was hardly a religious apologist of the kind that most critics of theology have in mind. 14 The request for funding for theological research and publication is not likely to become quantitatively comparable to that for funding of separate schools; and more importantly, support for such research and publication does not in any way jeopardize the survival of research and publication in other, secular areas. In any event, such funding could be provided on the basis of the same forms of careful peer appraisal that obtain elsewhere in the scholarly community.

(3) Although I do not endorse the view of certain fundamen- 
talist and other religious critics that there is a conspiracy in our public schools to promote the anti-religious ideology of secular humanism-and am indeed inclined to believe that, for better or for worse, the public schools generally tend to promote religion as such in many subtle ways - I cannot see any good reason for discouraging such critics from both being vigilant and articulating in their own educational programmes and in the public forum where they feel that the knowledge claims of public school teachers have not been adequately supported. Indeed, all citizens should be vigilant to insure that public schools are as neutral as possible in practice as well as in principle with respect to questions of religious doctrine.

(4) Finally, if theology is indeed a science, a properly intellectual pursuit, then in the long run it stands to be advanced rather than retarded by being protected by the principles of intellectual and academic freedom that have served scientists and intellectuals in other areas, and civilization itself, so well. If it is to deserve a place among the intellectual disciplines taught in a curriculum, it will have to be more than religious indoctrination. 


\section{Notes}

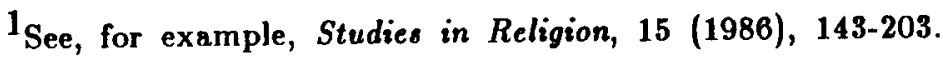

2 Ibid., p. 143.

$3_{\text {John Henry Newman, The Idea of a University, (1852-9), Part }}$ 1, Discourse 5, sec. 1.

4 Ibid., Part 1, Discourse 2, intro.

5 lbid., Part 1, Discourse 2, sec. 1.

${ }^{6}$ Cf. The Letters and Diaries of John Henry Newman, ed. Charles Stephen Dessain, Vol. 16: Founding a University (London: Thomas Nelson and Sons, 1965).

$7_{\text {Newman is undoubtedly alluding here primarily to such }}$ English "liberals" as Bentham and Brougham. Cf. Jay Newman, The Mental Philosophy of John Henry Newman, (Waterloo, Ontario: Wilfrid Laurier University Press, 1986), pp. 29-34.

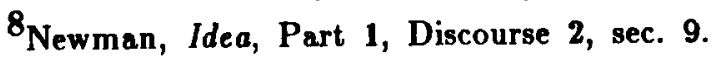

9 Ibid., Part 1, Discourse 2, sec. 2.

10 lbid., Part 1, Discourse 3, sec. 10.

11 lbid., Preface.

12 Cf. n. 3 above.

13 I have addressed these subjects at greater length in Foundations of Religious Tolerance (Toronto: University of Toronto Press, 1982).

${ }^{14}$ Aristotle, Metaphysice, 983a, 1026a. 